\title{
Time dimensions of job autonomy in R\&D work
}

\author{
Raul Ruubel ${ }^{1}$ \\ Department of Economics and Finance \\ Tallinn University of Technology, Estonia
}

\begin{abstract}
This paper seeks to identify what type of employees are more likely to be satisfied with flexible working time and what type with fixed time, and what drives some other time related aspects of job autonomy, using multivariate ordered probit modelling on data from an original repeated survey of Estonian creative R\&D employees. The results indicate that high creative intensity of work is a strong predictor of an R\&D employee being satisfied with flexible rather than fixed working schedules. Women and employees with less creative and more administrative tasks perceive more constraints on the timing of their work due to jealousy of colleagues and they are more likely to feel that their creativity is adversely affected by their working time arrangements. Employees with flexibility in both the timing and place of doing their work are significantly less likely to perceive working time related constraints on their creativity or jealousy of their colleagues as a restraint on their working time choices than are those with a fixed working time and place. The higher the salary level of the employee, the more likely they are to feel that the nature of their work constrains their working time choices. The study helps in understanding and alleviating restrictions on time-wise job autonomy that may have considerable adverse effects on how efficiently the intellectual capital of R\&D employees is used.
\end{abstract}

Keywords: Creative jobs, Flexibility, Job autonomy, Time use, Work arrangements

\section{Acknowledgements}

This project has received funding from the European Union's Horizon 2020 research and innovation programme under the Marie Skłodowska-Curie grant agreement No 734712. The author gratefully acknowledges support from grant PUT315 provided by the Estonian Research Council and support from the Doctoral School in Economics and Innovation, supported by the European Union, European Regional Development Fund (Tallinn University of Technology ASTRA project “TTÜ Development Program 2016-2022," project code: 2014-2020.4.01.160032. This research project has been approved by the Tallinn Medical Research Ethics Committee on 9 February 2015 by decision No. 894. The author is grateful to Professor Aaro Hazak, Professor Kadri Männasoo, Marko Virkebau and Erve Sõõru for making available the data from their survey for this study and for their valuable input in writing the paper. The author appreciates comments from seminar participants at the Department of Economics and Finance at Tallinn University of Technology.

${ }^{1}$ Raul Ruubel, Akadeemia tee 3, Department of Economics and Finance, Tallinn University of Technology, Tallinn, 12611, Estonia. Tel: +372620 3945, email: raul.ruubel@ttu.ee, ORCID: 0000-0001-9661-5699 


\section{Introduction}

Time has become an increasingly scarce resource in modern societies, where striving for more income has become a norm, and economies that cannot rely on cheap labour any more seek for ways to grow to meet the demands of their inhabitants for a better life. Economic growth through increased labour productivity requires jobs with higher added value and development through increasing reliance on knowledge intensive jobs is often the key for progress in both advanced and emerging economies. Powell and Snellman (2004) highlight how heavily development in knowledge based economies relies on intellectual capabilities rather than on physical inputs or natural resources, meaning that efficiency in creating and using the intellectual capital is crucial for growth. Clarke (2001) emphasises that while creation, transmission and use of information and knowledge is important, the effectiveness in gathering and utilising knowledge is a critical determinant of success.

While increasing knowledge intensity has meant a significant change in the structure of economies and in the nature of work, social norms on how work ought to be organised has not always followed these socio-economic transformations. As different people have different expectations for when, how much and how they would like to work, it is particularly important to arrange work so that the personal abilities of each employee are used efficiently and sufficient flexibility and autonomy is granted. This is not just a question of statutory and employer-level working time regulations, as the attitudes and potential jealousy of colleagues and other constraints on job autonomy may matter a lot for decisions on working time. The time arrangements of work have been studied from different angles, including analysis of benefits from the perspectives of both the employee and the employer (e.g. Kauffeld et al., 2004, Golden, 2009). However, little attention has been paid to the question of what type of individual is more likely to be satisfied with flexible work time arrangements and what type with fixed working time, and what the drivers are of other constraints on the desired freedom in working time decisions.

This study aims to help to fill this gap in the literature by focusing on some time related aspects of job autonomy that may contribute to more efficient use of human capital in knowledge work. The focus of the paper is creative R\&D employees as the driving force in the process of knowledge intensification and innovation. As enhancing economic growth through innovation is one of the main challenges in modern economies and innovation largely depends on human capital, then improving the time freedom of employees and their satisfaction with their working time arrangements may contribute considerably to the more efficient use of the creative potential of $R \& D$ employees.

\section{Literature review}

As the creative and intellectual efforts of knowledge employees are among the main drivers of $R \& D$ outcomes, the proper motivation, engagement and retention of $R \& D$ employees is critical for successful product development and innovation (Chang and Choi, 2007), along with proper funding of R\&D activities under regulatory and financing constraints (see e.g. Männasoo and Meriküll, 2014, Avarmaa et al. 2013, Männasoo et al. 2018, Hazak, 2008). For the right motivation package to be put in place and R\&D employees retained so that advantage can be 
achieved in knowledge based competition, it is important to have some insight into the factors that impact the performance of these employees and their attitude to work (Aryee and Leong, 1991). Abbey and Dickson (1983) study the work climate in $R \& D$, defined as the quality of the internal environment of an organisation resulting from the behaviour and policies of the members of that organisation, and found that fair and appropriate reward and a willingness to try new procedures and experiment with change were related to a number of innovations. They find the impact of job autonomy on the R\&D outcomes to be insignificant though, while Zampetakis et al. (2010), focusing on time management through activities to make the use of time more effective, which should facilitate productivity and relieve stress, find that daily and long term planning, time management and perceived control of time are all positively related to self-perceived creativity.

Goswami et al. (2007), referring to earlier literature, highlight that R\&D professionals are likely to prefer autonomy and flexibility in their work. Similarly, Mumford (2000) explores the management of creative people and points out that promoting flexible work schedules, telecommunicating and self-defined work plans is likely to contribute to innovation as outcomes of creative efforts are uncertain and employees need time for exploring and experimenting with different options and streams of thought. Further, creative people are typically autonomous and motivated in general, and so allowing them discretion in time management should have positive effects on their work outcomes. Pirola-Merlo et al. (2002) suggest that the working climate within an R\&D team plays an important role in its performance. Alshitri (2013) finds that colleagues, the nature of the work, supervision and compensation and promotion all impact the job satisfaction of R\&D employees. Similarly, Viñas-Bardolet et al. (2018) find that knowledge employees' job satisfaction is driven by colleague support, career advancement opportunities and job security as well as by flexible work schedules and work-family relations. Thamhain (2003) indicates that personal and professional needs, such as satisfaction and pride, interest, work challenges, accomplishments and recognition, all contribute to innovative performance.

Referring to previous studies, Ahuja et al. (2002) point out that autonomy at work where employees are able to schedule their work independently and discretionally and determine the work procedures needed is considered to improve work performance. They show that job autonomy is negatively associated with exhaustion at work and positively with job satisfaction. Moreover, autonomy helps reduce the probability of an employee switching employer through two channels, firstly through job satisfaction, which was found to be positively related to organizational commitment, which in turn is negatively related to turnover intention, and secondly through the positive impact on exhaustion, which reduces job satisfaction. Shih et al. (2011) focused on the impact of job autonomy on employee turnover intentions among IT professionals and found evidence that exhaustion at work is reduced when there is more job autonomy lessening the turnover intentions of employees. Support for the argument that autonomy increases job satisfaction has also been found by Taylor et al. (2003) and Saragih (2015), with Saragih also investigating how autonomy impacted job related stress but finding no evidence that it reduced job related stress.

Anttila et al. (2005) analyse the experiment of shorter working hours in Finnish municipalities and find the experiment to have had a positive impact on reducing work-family conflict, with employees with children seeing more of an impact. The second aspect of experiment, where the timing of work was changed, resulted at least partially in unsocial 
working hours, which were unpopular among the employees and resulted in a negative impact as job autonomy was reduced. The third element investigated by the Anttila et al. (2005) study was the use or tempo of working time, which is connected to overall well-being at work and at home. Among the employees who participated in the experiment, those who felt most exhausted at work were the ones who benefited the most from the reduced working hours. The experiment further revealed the additional interesting point that in a culture in which full-time work is seen as traditional, reduced working hours were found to cause feelings of guilt among some participants.

Eaton (2003) finds in a study of employees of biopharmaceutical firms that having formal or informal work-family policies is related with higher productivity, and the association is stronger where these policies are seen by the employees to be usable. Furthermore, control over time, flexibility, and the pace of work are all important in predicting positive levels of commitment and productivity for all employees. Wu et al. (2015) find that job autonomy could also buffer the negative effects of over-qualification on subjective well-being at work, though their study indicates that this is applicable only in individualistic cultures, as employees in such cultures tend to prioritise the pursuit of individual goals, with a focus on personal values, autonomy and self-fulfilment. Wenjing et al. (2013), like the present study, focus on knowledge employees and seek to identify factors which impact individual innovative performance and how job autonomy moderates creative personalities. Their results indicate that the younger the employee and the higher their education, the better their innovative performance is. The results also show the same relationship for job autonomy, so that the greater the autonomy, the better the employees creative performance. Wang and Cheng (2010) also find support for job autonomy having a positive impact on creativity.

One of the most common policies for increasing the autonomy of employees is the introduction of flexible working time arrangements, and this has become more common in recent years, with a large number of employers providing opportunities for flexible working time at least to some extent, and a wide range of employees keen to profit from these opportunities (De Menezes and Kelliher, 2017). While flexible working time arrangements have become more common, many studies have shown that they are not offered on an equal and fair basis to all employees. Golden (2001) finds for example that while over a quarter of US workforce have reported flexibility in their work schedules, the probability of being given a flexible work schedule depends on individual characteristics such as education, race, sex and marital status, where the probability is smaller for women and the less educated. There are several studies which outline the benefits of flexible working time arrangements from the perspective of the employee, the employer or both. Golden (2009) concludes that the motivations for an employer to offer flexible schedules include enhancement of on-the-job performance; a boost to the labour effort or a reduction in unscheduled absences or breaks, sick leave, tardiness, and employee work stress; improved retention of specific human capital, particularly in highly valued positions; and easier recruitment of new employees without having to escalate monetary compensation. Kauffeld et al. (2004) results show that employees with flexible working time options tend to be more loyal towards the company's goals and have a lower degree of absenteeism and higher quality of work.

From an employee perspective Butler et al. (2009) find that greater levels of flexibility are associated with better health. Similar associations have been found in other studies, e.g. 
Janssen and Nachreiner (2004) and Moen et al. (2011). The findings of Kauffeld et al. (2004) suggest that allowing flexitime leads to positive effects on the personal development and learning opportunities of employees. Moreover, several studies have highlighted the positive impact that flexible work schedules have in reducing work-family conflict (e.g. Hayman, 2009; Tausig and Fenwick, 2001). Virkebau and Hazak (2017) find that there are two streams of reasons why R\&D employees prefer flexible working time options, these being the expected positive effects on work outcomes, and the positive impact on social and family-related affairs. Giannikis and Mikhail (2011) propose that employees are more likely to opt for a flexible working time option if it helps them achieve the work-life balance they desire, while the probability decreases if employees recognise there will be a negative impact on their career progress, relationships with colleagues and compensation. McNamara et al. (2012) also find that the perceived negative effect on career progress is the main reason employees do not opt for flexible working time, whereas Almer et al. (2003) conclude that the attitude of colleagues is an important factor when people consider whether to opt for a flexible working arrangement.

However, Albion (2004) suggests that the reasons for opting for flexible working time outweigh the perceived barriers to it. Although previous studies have found that women are less likely to have access to flexible working time options than men are (e.g. Golden, 2001, 2008; Atkinson and Hall, 2009), they take those options up more than men do (Giannikis and Mikhail, 2011; Kossek et al., 1999). The decision to use the option of flexible working time is mainly driven by family responsibilities, which could explain these findings (Albion, 2004; Sarbu, 2014). Bailey and Kurland (2002) outline work-related factors, such as the willingness of the manager, workplace interaction, household distractions, a preference for working in a team, and self-perceived job suitability as indicators that predict whether an employee would opt to work remotely. Kossek et al. (1999) find that younger employees are more likely to use flexible working time, though it depends on whether team members have similar working schedules. Sharpe et al. (2002) also find support for the finding that younger employees are more likely to use flexible working time options, as are those with a higher level of education and employees with young children, as such employees see more positive effects of flexibility.

The changing environment means the culture of organizations is constantly shifting. Kalleberg (2001) highlights that social and economic changes emphasise the need for organisations to have greater flexibility in their employment systems. However, such changes could trigger new challenges. Allvin (2004) argues that the diversity of working conditions, which is one of most prominent features of today's labour market, leads to a mixture of rules, placing employees in different conditions, sometimes even within the same place of work. This can cause social tension and stress, as an employee with flexible working conditions within an otherwise traditionally organised workplace could be a focus of attention and envy, while an employee who insists on sticking to traditional working conditions in an otherwise flexible workplace may, likewise, be a source of irritation. Felstead et al. (2003) note that a number of managers and employees perceive telework as a potential threat to team integration, mainly because it weakens the ties between employees who enjoy the opportunity of teleworking and team members who remain in the place of work, which could generate resentment and lead to tensions. They stress that such resentments could be intensified by envy among on-site workers of the spatial and temporal discretion afforded to teleworking employees. Greer and Payne 
(2014) also point out that the lack of face-to-face communication and interdependency of teamwork are among the main challenges of teleworking.

To conclude, using human capital efficiently in knowledge work is a key determinant of success in today's knowledge-based economies, where creative employees are the main drivers of the innovation process. Previous studies suggest that, overall, job autonomy increases self-perceived creativity, and it also increases job satisfaction and reduces work exhaustion. The most common way of increasing job autonomy is to allow flexible working time options, including teleworking. Extant studies have highlighted several positive impacts that flexible working time options can have, such as enhancing on-the-job performance, reducing work stress, helping retain employees, increasing employee loyalty towards company goals, improving health, aiding employees' personal development and learning opportunities, and reducing conflict between work and family. However, the use of flexible working time options may also have downside such as envy from colleagues and constraints on team integration. These multifaceted linkages between individual characteristics, job specifics, job autonomy, working time arrangements and work outcomes, together with the need for social innovation in work arrangements (Hazak et al., 2016), justify the need for the current study, which seeks to identify the type of employee that is more likely to be satisfied with flexible working time arrangement and the type that prefers fixed arrangements, and what the drivers are of some other time-related aspects of job autonomy.

\section{Data and Methodology}

This study draws on an original repeated questionnaire survey among creative R\&D employees in Estonia, conducted in two waves in spring-summer 2015 and winter 2016. The sample was formed from the latest available (2012) R\&D data retrieved from Statistics Estonia. The study sample builds on the "researchers" category of the R\&D employees, and "technicians" and "supporting staff" have been left out as the nature of their work may not be creative. Over 20102014, the number of creative R\&D employees in Estonia has ranged between 4.1 and 4.6 thousand full time equivalent.

Creative R\&D employees who were working in higher education and healthcare were disregarded when the study sample was compiled, as work schedules in such institutions significantly interfere with the job autonomy that this study considers. In addition, R\&D employees working at micro-entities with less than 15 creative R\&D employees were excluded because the context of job autonomy in such companies is substantially different from what it is in larger organisations. After these exclusions, the population of interest for this study totals approximately 1.0 thousand. That population represents 23 employers, both private companies and public research institutes, of which 11 employers agreed to participate in the study.

Further eliminations from the sample were made if the survey participants had provided inconsistent responses to certain control questions or if their engagement in creative $R \& D$ activities for their employer was not sufficiently high. The final sample of 146 employees whose responses to the survey were taken into account forms 15 per cent of the total population of interest.

Mann-Whitney U tests (Mann and Whitney, 1947) were performed on the variables for time-related job autonomy, in order to identify the statistical significance of the differences in 
the responses of the 34 recurring respondents. As the differences in their responses in the two waves were statistically insignificant, the data from both waves of the survey were pooled and which of the recurring participants' responses to use for the analysis was selected randomly.

Participation in the survey was voluntary and confidential for the employees. However, the creative $R \& D$ employees in the population could only be included in the sample if their employer agreed to participate in the study, leading to potential for selection bias at the employer level. Completing the survey might also have incurred some employee level selection bias among respondents. These biases are addressed through sample weights that bring the final sample into alignment with the characteristics of the population of interest in terms of the gender of the respondent and the business of the employer. Clustering of standard errors by employers or employer-gender interactions in the econometric models provides further ways of considering unobserved dependencies in clusters by the different employers.

The dependent variables in the regression models comprise various time-related aspects of job autonomy. These represent 5-level Likert type scale responses on the scale (1) "Not at all"; (2) "To a small extent"; (3) "Somewhat"; (4) "To a large extent"; and (5) "Totally" to the following survey questions: (1) "To what extent are you satisfied with your current work time arrangement?" (dependent variable content); (2) "To what extent does your current working time arrangement have a negative effect on your creativity?" (creaimpede); (3) "To what extent can you decide yourself about the speed of work and the time for breaks when you at work?" (pace); (4) "To what extent do restrictions arising from the nature of your work cause your working day not to start and end at the times that you would prefer?" (worknature); (5) "To what extent does discontent and potential jealousy from colleagues cause your working day not to start and end at the times that you would prefer?" (colleagues).

Figure 1 presents the distribution of the Likert type scale responses in the sample for each of the dependent variables. In the case of content the split between employees who have flexible working time (flextime $=1$ ) and those who have rigid working hours (flextime $=0$ ) has been shown.
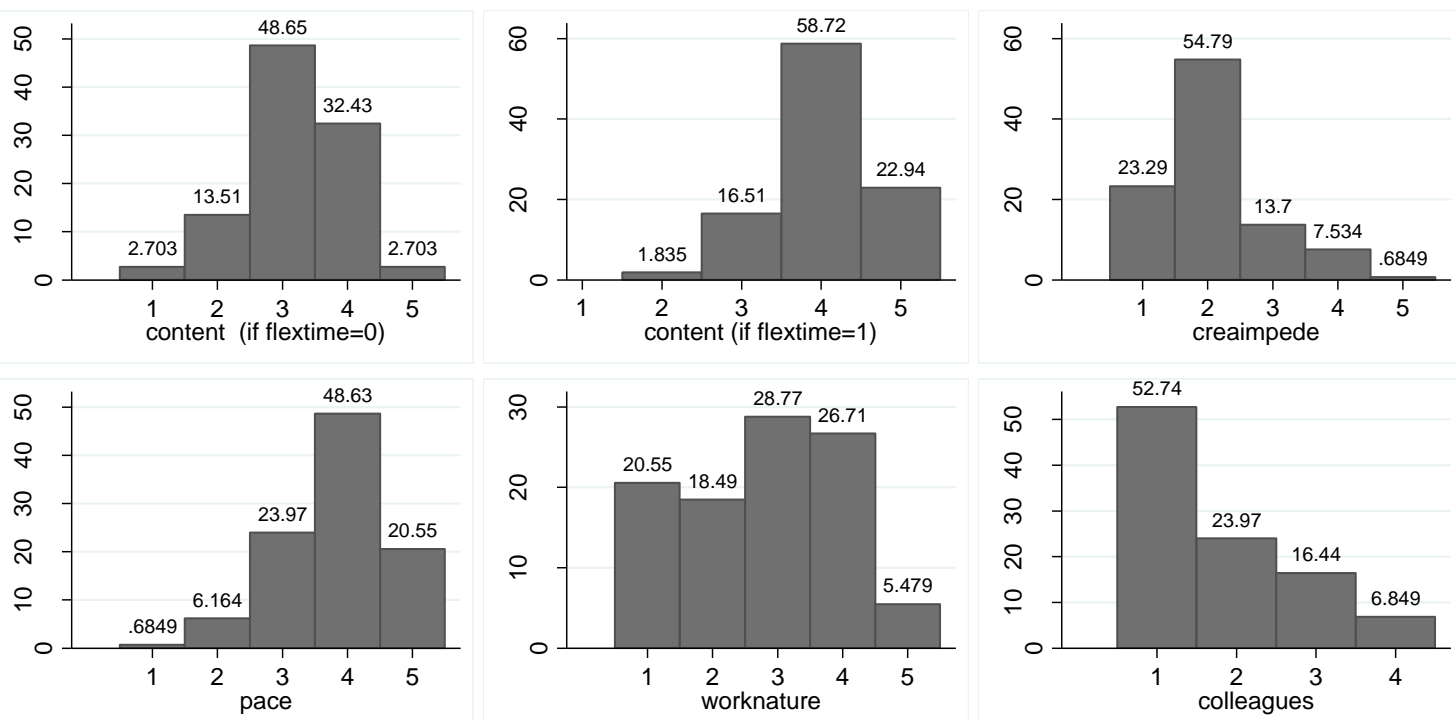

Figure 1 Histograms of dependent variables 
The explanatory variables have primarily been selected following the earlier literature. Several explanatory variables reflect various aspects of the arrangement of work - the creative intensity of work, the availability of flexitime, the option of working from distance, average daily working hours and the proportion of working hours worked at the place of work, and the nature of the employment contract. Age, gender, number of family members and level of education have been incorporated as measures of the key socio-demographic characteristics of the employee. The first principal component score of various health measures controls for the general health condition of the respondent while the sleep patterns of the employee are reflected through the score of the Reduced Morningness-Eveningness Questionnaire ( $m e q$ ) by Adan and Almirall (1991) and average daily sleeping hours. In addition, the salary level of the employee and area of business of the employer are included as independent variables. The explanatory variables have been outlined in Appendix A1 along with the sample description.

Since all the dependent variables constitute ordered discrete categories, ordered probit regression analysis was used for the estimations. Moreover, to account for the interrelations between the individual measures of time-related job autonomy, simultaneous multivariate ordered probit regression modelling of creaimpede, pace, worknature and colleagues was used. The numeric results of the regression models are presented in Appendices A2 (ordered probit models) and A3 (multivariate ordered probit model), and these are explained and discussed in the following section.

\section{Results and Discussion}

The results of Models 1 and 2 help to understand what type of employees are satisfied with fixed working time and what type of employees prefer flexible arrangements. The creative intensity of work appears a robust predictor of satisfaction with either fixed or flexible working time arrangements. The higher the share of creative tasks in total working time, the higher the probability that the employee is totally satisfied with flexible working schedules (right panel of Figure 2) and the less likely it is that they prefer rigid working schedules (left panel of Figure 2).
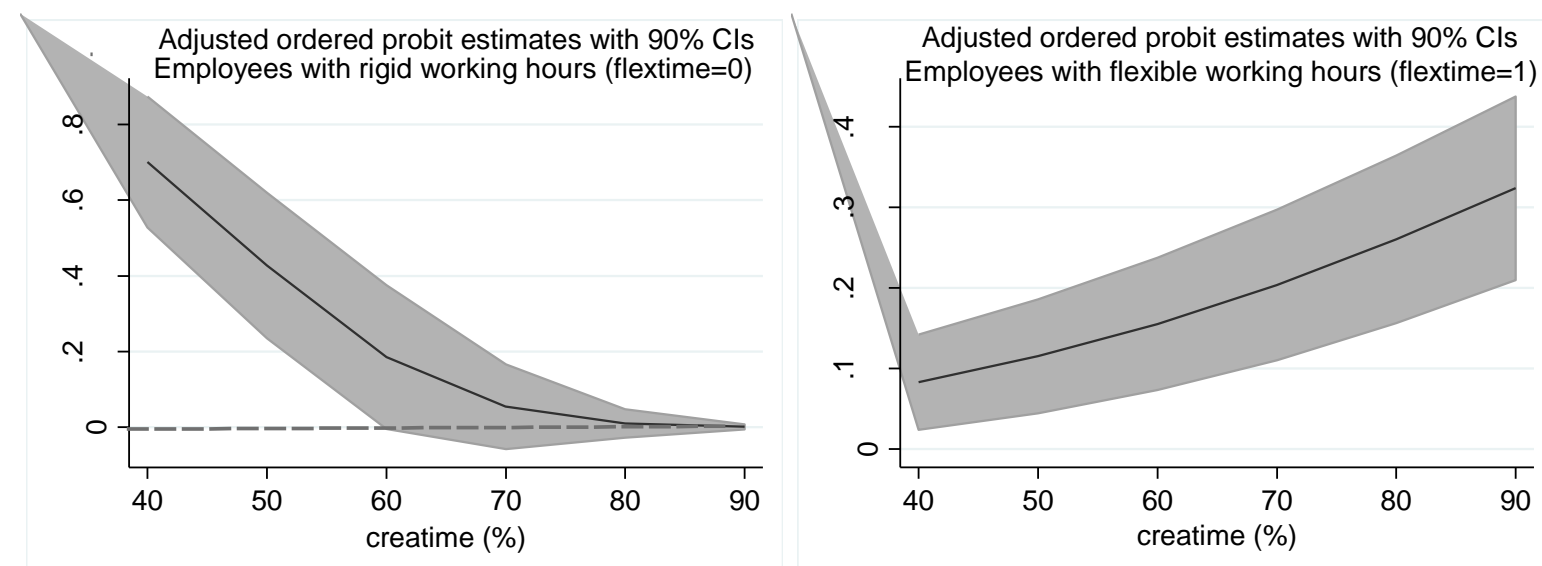

Figure 2 Content with rigid (left) and flexible (right) working time under different levels of creative intensity of work 
The option of teleworking is another key factor closely related to satisfaction with working time arrangements. Employees with flexible work schedules who can work from distance have a probability of $35 \%$ of being totally satisfied with their working time arrangements, while the probability is $8 \%$ for those who can use flexitime but cannot use teleworking, assuming other variables at their mean levels. Moreover, the actual use of the distance work option has a significant positive effect on how satisfied the employee is with their working time arrangements. The larger the share of total working time that the employee works at the place of work, the less content they are with their working time arrangements. This can be said of employees with flexible working schedules, while there are only four employees in the sample who have a distance work option but rigid working hours, which is not a surprise as distance work usually comes together with flexible schedules.

As regards individual characteristics, age is an important determinant of how satisfied employees are with fixed or flexible schedules. As illustrated in Figure 3, the younger the employee is, the more likely they are to be totally satisfied with working time arrangements if they can use flexitime (right panel), while older employees tend to be more content with working time arrangements under fixed schedules (left panel).
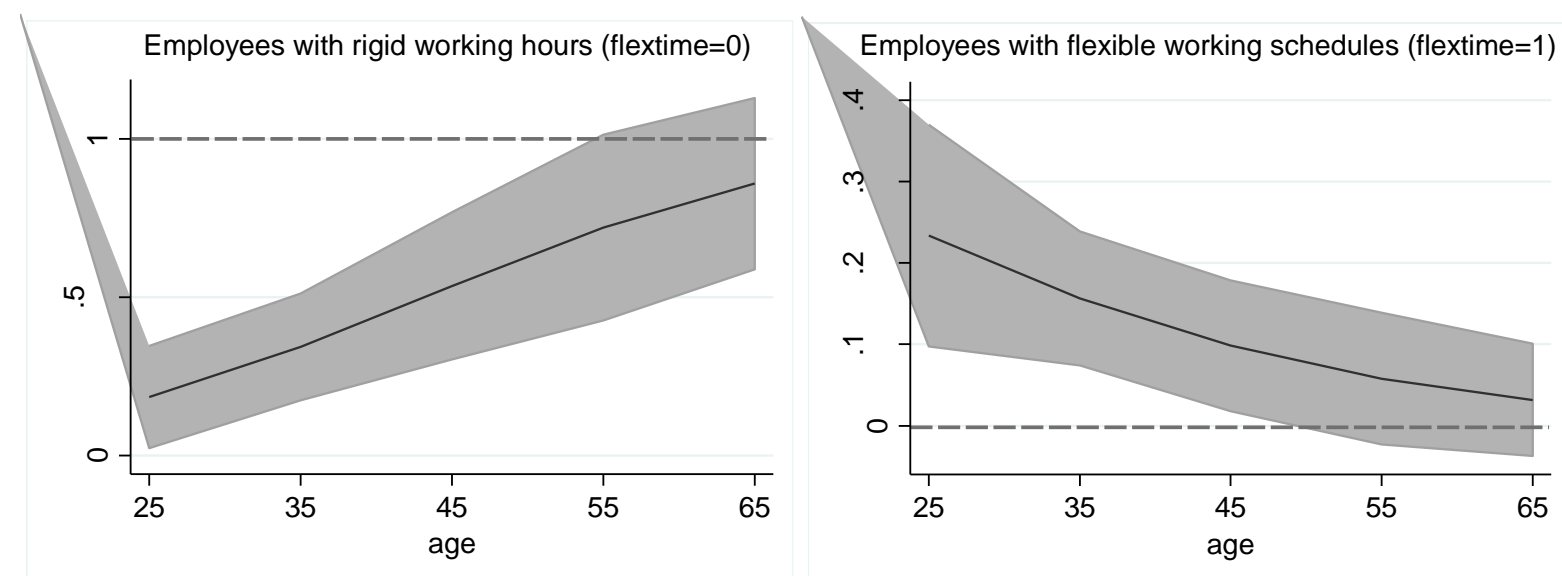

Figure 3 Contentment with rigid (left) and flexible (right) working time for different ages of the employee (with $90 \%$ confidence intervals)

Gender is another individual characteristic that determines whether the creative R\&D employee is satisfied with their working time arrangements, but gender does not appear to differentiate clearly the preference for rigid or flexible working hours. Overall, men appear more satisfied with their working arrangements than women, whether they have fixed or flexible schedules. Assuming other variables at their mean, male employees with flexitime have a probability of $17 \%$ of being totally satisfied with their working time arrangements, while the probability is $8 \%$ for female employees who can use flexible work schedules. Among those who work with rigid working hours, men are 30 percentage points more likely than women to be largely satisfied with their working time arrangements.

The results of Model 2 indicate that among employees with flexible working time, morning type people are significantly more likely to be totally satisfied with their working time arrangement, as illustrated in the left panel of Figure 4. The morningness-eveningness effect on 
satisfaction with working time arrangements is not visible among employees with fixed schedules though.
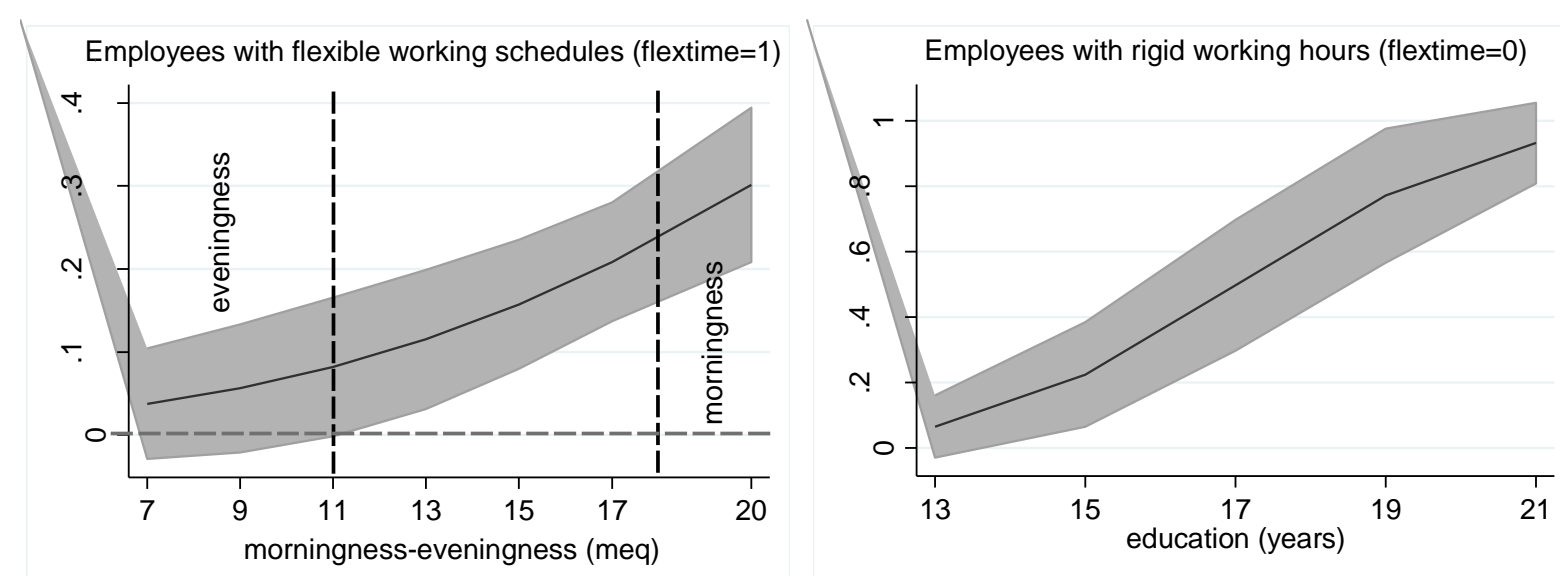

Figure 4 Content with flexible working time in morning and evening types (with 90\% confidence intervals)

The results from Model 1 indicate that when employees with higher education have fixed working time, they are more likely to be satisfied to a large extent with their working time arrangements than are employees with lower levels of education (see the right panel of Figure 4). No statistically significant similar relationship appears for those working with flexitime.

The study finds some weaker support for sectoral differences. Model 1 reveals that creative $R \& D$ employees in private $R \& D$ companies are more satisfied with their working arrangements under fixed schedules than are those working in public R\&D entities. In a similar vein, Model 2 shows that creative R\&D employees in IT and technology companies are less satisfied with their working arrangements under flexible schedules than are the creative employees of public R\&D institutes.

For a robustness check, these models were alternatively estimated with either salary, sleep hours or timeshare eliminated from the explanatory variables in the models, but this did not lead to any significant differences in the results. Equally, alternative ways of clustering standard errors were tested but the results remain qualitatively similar. These alternative modelling results are available upon request from the author.

The next set of results concerns perceived constraints on creativity deriving from working time arrangements. Flexible working arrangements have a significant effect on how severely employees feel working time-related constraints impinge on their creativity. The probability of an employee perceiving that their current working time arrangement has a somewhat negative effect on their creativity is $3 \%$ among those who have flexibility in both the time and the place that they work, but $8 \%$ for those who enjoy only flexitime, and $12 \%$ for employees without any flexibility in either their working time or their working place, provided other variables are at their means.

There are significant gender differences in how intensely employees perceive timerelated limitations on their creativity. The likelihood of male employees perceiving that their working time arrangement has a somewhat negative effect on their creativity is $5 \%$ but for female employees it is $14 \%$, assuming other variables are at their means. 
As illustrated in Figure 5, the higher the employee's level of education and the higher the creative intensity of their work, the lower is the likelihood that they will perceive working timerelated constraints on their creativity. These effects are related to each other as employees who have spent more years in education are more likely to get or opt for positions with a higher creative intensity (Hazak et al., 2017).
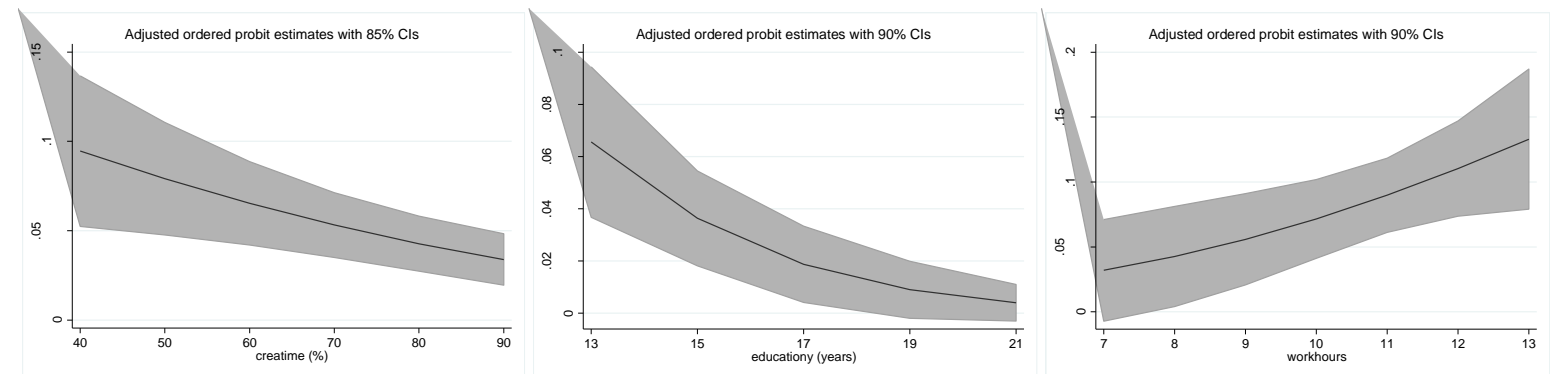

Figure 5 Probabilities of an employee perceiving constraints on their creativity due to working time arrangements

As expected, employees whose working days are longer perceive constraints from working time arrangements on their creativity more intensely (rightmost panel in Figure 5). There appear to be significant sectoral differences in this, with creative $R \& D$ employees in the private sector having a higher likelihood by 9 to 11 percentage points of perceiving some working time-related constraints on their creativity than their colleagues in public research institutes.

Another dimension of job autonomy that the study results address is the extent to which the creative R\&D employee can decide for themselves about the speed of work and the time for breaks. The availability of flexible working schedules and distance work options are among the key drivers of that measure of job autonomy as well. While employees with rigid working hours and a fixed place of work have a probability of $12 \%$ of being totally in control of the pace of their work, the probability in those with flexible schedules but a fixed working place is $15 \%$ and in those with flexibility in both the time and place of work it is as high as $38 \%$. This study finds some evidence that older creative R\&D employees and those in weaker general health perceive better control of the pace of their work. Morning type employees also have a higher likelihood of being in better control of the speed of their work and the time for breaks. Creative R\&D employees of IT and technology companies and banks do not appear to exercise as much control over their working pace as their colleagues in public R\&D institutions.

Model 5 aims to identify some key drivers of the extent to which restrictions arising from the nature of the work cause the working day of the employee not to start and end at the times that they would prefer. The lower the creative intensity of work, the greater the perceived constraints from the nature of the work on the start and end time of work are. Those with a fixed terms employment contract and with a higher salary level appear to be more likely to feel these constraints as well (see left panel of Figure 6). Weaker general health appears to be positively related with the perceived extent to which restrictions due to the nature of work cause the workday not to start and end at preferred times. The explanatory power of Model 5 remains quite low however with pseudo-R-squared of 0.06 . 
The study provides an interesting insight into the perceived discontent and potential jealousy from colleagues as a cause for workday not starting and ending at the times that the employee would prefer. The lower the creative intensity of the work, the higher the likelihood of the employee perceiving such constraints on their job autonomy. See the right panel of Figure 6 for an illustration of that relationship. Employees who are granted flexibility in both the timing and place of their work have a significantly lower probability of perceiving these constraints than do those with a fixed working place and rigid schedules. While men have a $1.7 \%$ probability of feeling to a large extent that discontent and potential jealousy from colleagues causes their working day not to start and end at their preferred times, the probability for women is $4.3 \%$.
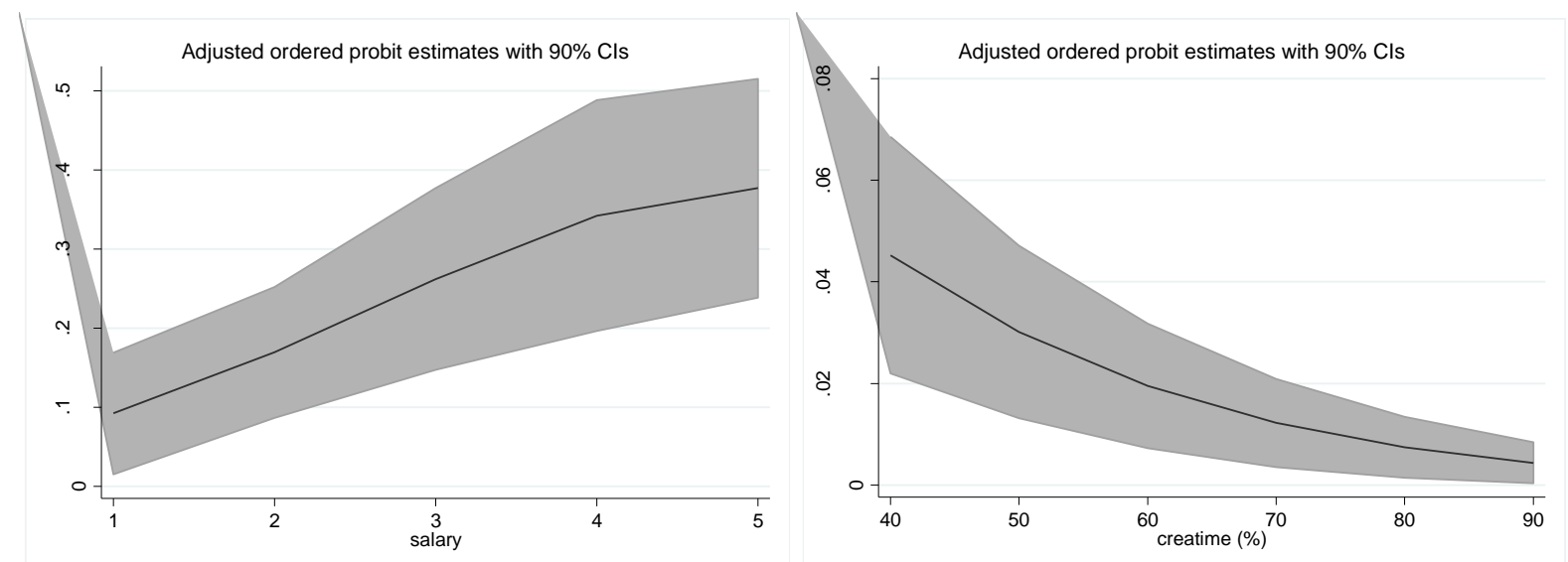

Figure 6 Probabilities of an employee perceiving constraints on the start and end time of their working day from the nature of the work

The alternative multivariate ordered probit estimates presented in Table A3 in the Appendix provide similar results to the ordered probit estimates in Models 3-6. An interesting additional insight that the multivariate ordered probit estimates provide is the interrelations between the regression estimates of the four dependent variables (see the atanhrho estimates in Table A3). It appears that there is a significant positive relationship between the perceived jealousy of colleagues as a cause for undesired start and end times of the working day and the perceived extent of working time arrangements having a negative effect on the creativity of the employee. Moreover, the drivers of the latter two perceptions perceived appear to be strongly related to the determinants of low control over the pace of work.

\section{Discussion and Conclusions}

This paper investigates the drivers of various aspects of job autonomy in terms of working time arrangements and it presents ordered probit and multivariate ordered probit regression estimates, based on data from an original repeated survey of Estonian creative R\&D employees on a sample of eleven employers and 146 employees.

This study finds that the higher the creative intensity of work of an R\&D employee is the more likely the employee is to be satisfied with flexible rather than with fixed working schedules. Moreover, both the availability of distance work options and their actual use have a 
positive effect on how content creative employees are with their working time arrangements. This study reveals that flexible work is strongly linked to another dimension of time-related job autonomy, which is the extent to which creative R\&D employees can decide for themselves about the speed of their work and the time they take breaks. While employees with rigid working hours and a fixed place of work have a probability of $12 \%$ of being totally in control of the pace of their work, the probability for those with flexible schedules but a fixed working place is $15 \%$ and for those with flexibility in both working time and the place of work it is as high as 38\%. These findings are in alignment with the argumentation of Goswami et al. (2007) and Mumford (2000), among others, suggesting that employees who are devoted to creative R\&D work prefer and need autonomy and flexibility in their work arrangements.

Another finding is that women and employees with less creative work and more administrative and other non-creative tasks perceive more constraints on the start and end times of their work because of the discontentment and jealousy of their colleagues. Moreover, they are more likely to perceive that their working time arrangements affect their creativity adversely. Although this is broadly in alignment with the argument of Allvin (2004) and Felstead et al. (2003) that discontentment rises among colleagues when flexible work arrangements are used more, it is a novel finding, suggesting that employees whose position may be more vulnerable, like women rather than men, or whose work behaviour attracts more attention like staff with administrative duties rather than fully creative employees, appear more likely to become targets of the jealousy of colleagues if they start using more flexible working time options. This finding, complementing Ruubel and Hazak (2018), is important in highlighting that allowing the use of flexible working time alone may not be sufficient to make employees enjoy freedom in their working time. Employers seeking to implement flexible work practices should deal with the attitudes and behaviours of employees towards job autonomy in order to take full benefit from flexible work options.

This study demonstrates that employees who have flexibility in both the timing and the place of their work are significantly less likely to perceive working time-related restraints on their creativity or to see the jealousy of their colleagues as a constraint on their working time choices than are those with a fixed working time and place. This finding follows in general the outcomes of Giannikis and Mikhail (2011), McNamara et al. (2012) and Almer et al. (2003), which all suggest that employees would be more likely to start using flexible working options if doing so contributes to achieving the desired work-life balance without hindering relationships with colleagues. Another explanation could be however that those working from distance are out of sight of their colleagues and can thus decide more freely about the start and end times of their working day, which in turn facilitates their creativity. In any case, the finding suggests once again that behavioural aspects are important in how efficiently flexible work options are implemented and the availability of flexitime alone does not yet mean it fulfils its purpose in improving work outcomes and employee wellbeing.

Another interesting finding from this study is that a higher salary level increases the likelihood that the employee will perceive the nature of their work to constrain their working time choices. This novel finding may be explained by the stronger attachment of more highly paid employees to their job and increased job insecurity, which in turn may have an adverse effect on job autonomy in terms of time freedom. This phenomenon warrants further study in order to understand whether a higher salary functions as a way of compensating a creative 
employee for reduced job autonomy, which may appear beneficial to the employer in the shorter term but may have considerable adverse effects in the longer term if it reduces the productivity of the time constrained creative employee.

Further findings of the study point to various individual characteristics like age, education, health and sleep patterns being related to time-wise job autonomy. The employer's industry and whether the job is fixed term or permanent appear to be connected to job autonomy and working time flexibility.

The outcomes of this study may be useful for R\&D companies in understanding the complicated nature of job autonomy in terms of time freedom and the role of various behavioural aspects in implementing flexible work options. In addition to making flexible work available formally, it is important for employers to consider the individual characteristics of the employees and the reactions of their colleagues when assessing the utility of flexible work in practice.

\section{References}

Abbey, A. and Dickson, J.W., 1983. R\&D work climate and innovation in semiconductors. Academy of Management Journal, 26(2), pp.362-368.

Adan, A. and Almirall, H., 1991. Horne \& Östberg morningness-eveningness questionnaire: A reduced scale. Personality and Individual differences, 12(3), pp.241-253.

Ahuja, M., Chudoba, K.M., George, J.F., Kacmar, C. and McKnight, H., 2002, January. Overworked and isolated? Predicting the effect of work-family conflict, autonomy, and workload on organizational commitment and turnover of virtual workers. In System Sciences, 2002. HICSS. Proceedings of the 35th Annual Hawaii International Conference on (pp. 3586-3593). IEEE.

Albion, M.J., 2004. A measure of attitudes towards flexible work options. Australian Journal of Management, 29(2), pp.275-294.

Allvin, M., 2004. The individualization of labour. Learning to be Employable.

Almer, E.D., Cohen, J.R. and Single, L.E., 2003. Factors affecting the choice to participate in flexible work arrangements. Auditing: A Journal of Practice \& Theory, 22(1), pp.6991.

Alshitri, K.I., 2013. An investigation of factors affecting job satisfaction among R\&D center employees in Saudi Arabia. Journal of Human Resources Management Research, p.1.

Anttila, T., Nätti, J. and Väisänen, M., 2005. The experiments of reduced working hours in Finland: impact on work-family interaction and the importance of the sociocultural setting. Community, Work and Family, 8(2), pp.187-209. 
Aryee, S. and Leong, C.C., 1991. Career orientations and work outcomes among industrial R\&D professionals. Group \& Organization Studies, 16(2), pp.193-205.

Atkinson, C. and Hall, L., 2009. The role of gender in varying forms of flexible working. Gender, Work \& Organization, 16(6), pp.650-666.

Avarmaa, M., Hazak, A. and Männasoo, K., 2013. Does Leverage Affect Labour Productivity? A Comparative Study of Local and Multinational Companies of the Baltic Countries. Journal of Business Economics and Management, 14(2), pp.252-275.

Bailey, D.E. and Kurland, N.B., 2002. A review of telework research: Findings, new directions, and lessons for the study of modern work. Journal of organizational behavior, 23(4), pp.383-400.

Butler, A.B., Grzywacz, J.G., Ettner, S.L. and Liu, B., 2009. Workplace flexibility, selfreported health, and health care utilization. Work \& Stress, 23(1), pp.45-59.

Chang, J.Y. and Choi, J.N., 2007. The dynamic relation between organizational and professional commitment of highly educated research and development (R\&D) professionals. The Journal of Social Psychology, 147(3), pp.299-315.

Clarke, T., 2001. The knowledge economy. Education+ Training, 43(4/5), pp.189-196.

De Menezes, L.M. and Kelliher, C., 2017. Flexible Working, Individual Performance, and Employee Attitudes: Comparing Formal and Informal Arrangements. Human Resource Management, 56(6), pp.1051-1070.

Eaton, S.C., 2003. If you can use them: Flexibility policies, organizational commitment, and perceived performance. Industrial Relations: A Journal of Economy and Society, 42(2), pp.145-167.

Felstead, A., Jewson, N. and Walters, S., 2003. Managerial control of employees working at home. British Journal of Industrial Relations, 41(2), pp.241-264.

Giannikis, S.K. and Mihail, D.M., 2011. Flexible work arrangements in Greece: a study of employee perceptions. The International Journal of Human Resource Management, 22(02), pp.417-432.

Golden, L., 2001. Flexible work schedules: Which workers get them?. American Behavioral Scientist, 44(7), pp.1157-1178.

Golden, L., 2008. Limited access: Disparities in flexible work schedules and work-at-home. Journal of Family and Economic Issues, 29(1), pp.86-109.

Golden, L., 2009. Flexible daily work schedules in US jobs: Formal introductions needed?. Industrial Relations: A Journal of Economy and Society, 48(1), pp.27-54. 
Goswami, S., Mathew, M. and Chadha, N.K., 2007. Differences in occupational commitment amongst scientists in Indian defence, academic, and commercial R\&D organizations. Vikalpa, 32(4), pp.13-28.

Greer, T.W. and Payne, S.C., 2014. Overcoming telework challenges: Outcomes of successful telework strategies. The Psychologist-Manager Journal, 17(2), p.87.

Hayman, J.R., 2009. Flexible work arrangements: Exploring the linkages between perceived usability of flexible work schedules and work/life balance. Community, Work \& Family, 12(3), pp.327-338.

Hazak, A., 2008. Profit vs. Distributed Profit Based Taxation and Companies' Capital Structure. International Journal of Entrepreneurship and Innovation Management, 8(5), pp.524541.

Hazak, A., Tint, P., Virkebau, M., Pille, V., Tuulik, V. and Sõõru, E. 2016. Social Innovation Potential in Working Arrangements of R\&D Employees: Repeated Employee Survey from Estonia. 2016 IEEE International Conference on Emerging Technologies and Innovative Business Practices for the Transformation of Societies (EmergiTech) (IEEE), pp.210-213.

Hazak, A., Männasoo, K. and Virkebau, M., 2017. Effects of Work Arrangements on Creative R\&D Work Outcomes. Eastern European Economics, 55(6), pp.500-521.

Janssen, D. and Nachreiner, F., 2004. Health and psychosocial effects of flexible working hours. Revista de saude publica, 38, pp.11-18.

Kalleberg, A.L., 2001. Organizing flexibility: the flexible firm in a new century. British Journal of Industrial Relations, 39(4), pp.479-504.

Kauffeld, S., Jonas, E. and Frey, D., 2004. Effects of a flexible work-time design on employeeand company-related aims. European journal of work and organizational psychology, 13(1), pp.79-100.

Kossek, E.E., Barber, A.E. and Winters, D., 1999. Using flexible schedules in the managerial world: The power of peers. Human Resource Management, 38(1), pp.33-46.

Mann, H.B. and Whitney, D.R., 1947. On a test of whether one of two random variables is stochastically larger than the other. The annals of mathematical statistics, pp.50-60.

McNamara, T. K., Pitt-Catsouphes, M., Brown, M., \& Matz-Costa, C. (2012). Access to and utilization of flexible work options. Industrial Relations: A Journal of Economy and Society, 51(4), 936-965. 
Männasoo, K., Maripuu, P. and Hazak, A., 2018. Investments, Credit, and Corporate Financial Distress: Evidence from Central and Eastern Europe. Emerging Markets Finance and Trade, 54(3), pp.677-689.

Männasoo, K., and Meriküll, J., 2014. R\&D, Credit Constraints, and Demand Fluctuations: Comparative Micro Evidence from Ten New EU Members. Eastern European Economics, 52(2), pp.49-64.

Moen, P., Kelly, E.L., Tranby, E. and Huang, Q., 2011. Changing work, changing health: can real work-time flexibility promote health behaviors and well-being?. Journal of Health and Social Behavior, 52(4), pp.404-429.

Mumford, M.D., 2000. Managing creative people: Strategies and tactics for innovation. Human resource management review, 10(3), pp.313-351.

Pirola-Merlo, A., Härtel, C., Mann, L. and Hirst, G., 2002. How leaders influence the impact of affective events on team climate and performance in $\mathrm{R} \& \mathrm{D}$ teams. The leadership quarterly, 13(5), pp.561-581.

Powell, W.W. and Snellman, K., 2004. The knowledge economy. Annu. Rev. Sociol., 30, pp.199-220.

Ruubel, R. and Hazak, A., 2018. Disparities in Knowledge Employees' Actual, Contractual and Desired Working Schedules. Knowledge Management: An International Journal, Forthcoming.

Saragih, S., 2015. The effects of job autonomy on work outcomes: Self efficacy as an intervening variable. International Research Journal of Business Studies, 4(3).

Sarbu, M., 2014. Determinants of flexible work arrangements.

Sharpe, D.L., Hermsen, J.M. and Billings, J., 2002. Factors associated with having flextime: A focus on married workers. Journal of Family and Economic Issues, 23(1), pp.51-72.

Shih, S.P., Jiang, J.J., Klein, G. and Wang, E., 2011. Learning demand and job autonomy of IT personnel: Impact on turnover intention. Computers in Human Behavior, 27(6), pp.2301-2307.

Tausig, M. and Fenwick, R., 2001. Unbinding time: Alternate work schedules and work-life balance. Journal of family and economic issues, 22(2), pp.101-119.

Taylor, J., Bradley, S. and Nguyen, A.N., 2003. Job autonomy and job satisfaction: new evidence.

Thamhain, H.J., 2003. Managing innovative R\&D teams. $R \& d$ Management, 33(3), pp.297311. 
Viñas-Bardolet, C., Torrent-Sellens, J. and Guillen-Royo, M., 2018. Knowledge Workers and Job Satisfaction: Evidence from Europe. Journal of the Knowledge Economy, pp.1-25. Virkebau, M. and Hazak, A., 2017. What Type of Research and Development Employees Use Flextime? International Journal of Organizational Diversity, 17(2), pp.1-9.

Wang, A.C. and Cheng, B.S., 2010. When does benevolent leadership lead to creativity? The moderating role of creative role identity and job autonomy. Journal of organizational behavior, 31(1), pp.106-121.

Wenjing, C.A.I., Wei, S.O.N.G. and Shuliang, Z.H.A.O., 2013. An empirical study on the effects of creative personality and job autonomy on individual innovation performance of knowledge workers. International Business and Management, 6(2), pp.24-30.

Wu, C.H., Luksyte, A. and Parker, S.K., 2015. Overqualification and subjective well-being at work: The moderating role of job autonomy and culture. Social Indicators Research, 121(3), pp.917-937.

Zampetakis, L.A., Bouranta, N. and Moustakis, V.S., 2010. On the relationship between individual creativity and time management. Thinking skills and creativity, 5(1), pp.2332. 


\section{Appendices}

Table A1. Explanatory variables and sample description

\begin{tabular}{|c|c|c|c|c|}
\hline Variable & Description & $\begin{array}{l}\text { All } \\
\text { Mean/\% } \\
\text { (Std. Dev.) }\end{array}$ & $\begin{array}{l}\text { flextime }=\mathbf{0} \\
\text { Mean/\% } \\
\text { (Std. Dev.) }\end{array}$ & $\begin{array}{l}\text { flextime }=1 \\
\text { Mean/\% } \\
\text { (Std. Dev.) }\end{array}$ \\
\hline & $\mathbf{N}$ & $146(100 \%)$ & $37(25 \%)$ & $109(75 \%)$ \\
\hline creatime & $\begin{array}{l}\text { Employee reported share of creative work in total working time } \\
\text { of the employee }(\%)\end{array}$ & $\begin{array}{l}52.29 \\
(21.64)\end{array}$ & $\begin{array}{l}48.51 \\
(19.24)\end{array}$ & $\begin{array}{l}53.58 \\
(22.33)\end{array}$ \\
\hline workhours & Employee reported average working hours per working day & $\begin{array}{l}10.12 \\
(1.69)\end{array}$ & $\begin{array}{l}9.95 \\
(1.61)\end{array}$ & $\begin{array}{l}10.17 \\
(1.72)\end{array}$ \\
\hline place & $\begin{array}{l}\text { It is possible }(=1) \text { vs not possible }(=0) \text { to work from a location } \\
\text { suitable for the employee (e.g. home) as often as he/she likes }\end{array}$ & $27 \%$ & $11 \%$ & $33 \%$ \\
\hline flextime & $\begin{array}{l}\text { Flexible }(=1) \text { vs fixed }(=0) \text { working time arrangement of the } \\
\text { employee }\end{array}$ & $75 \%$ & $0 \%$ & $100 \%$ \\
\hline atwork & Share of work hours at workplace from total work hours (\%) & $\begin{array}{l}82.0 \\
(12.85)\end{array}$ & $\begin{array}{l}86.2 \\
(9.2)\end{array}$ & $\begin{array}{l}80.5 \\
(13.6)\end{array}$ \\
\hline \multirow[t]{3}{*}{ nature } & "Permanent work" (base) & $90 \%$ & $97 \%$ & $88 \%$ \\
\hline & "Non-permanent work, with a duration of more than 1 year" $(=2)$ & $7 \%$ & $3 \%$ & $8 \%$ \\
\hline & "Non-permanent work, with a duration of less than 1 year" $(=3)$ & $3 \%$ & $0 \%$ & $4 \%$ \\
\hline \multirow{6}{*}{ salary } & Employee reported monthly gross salary on the scale: & & & \\
\hline & "Below 1000 euros" $(=1$, base $)$ & $7 \%$ & $11 \%$ & $6 \%$ \\
\hline & $" 1000-2000$ euros" $(=2)$ & $58 \%$ & $62 \%$ & $57 \%$ \\
\hline & “2000 - 3000 euros" $(=3)$ & $23 \%$ & $16 \%$ & $25 \%$ \\
\hline & “3000 - 5000 euros" $(=4)$ & $12 \%$ & $11 \%$ & $12 \%$ \\
\hline & "above 5000 euros" $(=5)$ & $1 \%$ & $0 \%$ & $1 \%$ \\
\hline age & Age in years & $\begin{array}{l}38.75 \\
(11.44)\end{array}$ & $\begin{array}{l}42.38 \\
(12.71)\end{array}$ & $\begin{array}{l}37.52 \\
(10.76)\end{array}$ \\
\hline gender & Male $(=1)$ vs female $(=0)$ & $56 \%$ & $43 \%$ & $61 \%$ \\
\hline family & $\begin{array}{l}\text { Employee reported number of people living together with the } \\
\text { employee }\end{array}$ & $\begin{array}{l}1.68 \\
(1.46)\end{array}$ & $\begin{array}{l}1.59 \\
(1.38)\end{array}$ & $\begin{array}{l}1.71 \\
(1.49)\end{array}$ \\
\hline education & Years of education starting from primary education & $\begin{array}{l}16.53 \\
(2.66)\end{array}$ & $\begin{array}{l}16.43 \\
(2.63)\end{array}$ & $\begin{array}{l}16.57 \\
(2.69)\end{array}$ \\
\hline phealth & $\begin{array}{l}\text { First principal component score of general health conditione with } \\
\text { overall Kaiser-Meyer-Olkin measure of sampling adequacy of } \\
0.6 \text {; comprises (1) "Do you have high blood pressure or have you } \\
\text { ever used medicine for high blood pressure?" (yes=1); (2) "Do } \\
\text { you suffer or have you suffered from diseases that significantly } \\
\text { affect your mental fatigue?" (5-level Likert type scale, } \\
\text { "Never"=1, "Often"=5); (3) "Does your disease or injury } \\
\text { interrupt you while doing your daily job?" (5-level Likert type } \\
\text { scale, "No obstacles"=1, "Not able to work"=5); (4) "How many } \\
\text { workdays have you been absent from work due to disease or } \\
\text { medical examination in the past } 12 \text { months?"(5-level scale, } \\
\text { "None" = 1, "100-365 days" = 5); (5) Body-Mass Index } \\
\text { (continuous) }\end{array}$ & $\begin{array}{l}0.00 \\
(1.41)\end{array}$ & $\begin{array}{l}0.13 \\
(1.50)\end{array}$ & $\begin{array}{l}-0.05 \\
(1.38)\end{array}$ \\
\hline meq & $\begin{array}{l}\text { rMEQ score, } 1 \ldots 25 \text { scale ranging from "Definitely an evening } \\
\text { type" to "Definitely a morning type" }\end{array}$ & $\begin{array}{l}14.72 \\
(3.55)\end{array}$ & $\begin{array}{l}14.73 \\
(3.46)\end{array}$ & $\begin{array}{l}14.72 \\
(3.60)\end{array}$ \\
\hline \multirow[t]{6}{*}{ sleephours } & Employee reported average sleeping hours per day on the scale: & & & \\
\hline & "Less than 6 hours" $(=1$, base $)$ & $5 \%$ & $8 \%$ & $5 \%$ \\
\hline & "6-7 hours" (=2) & $50 \%$ & $51 \%$ & $50 \%$ \\
\hline & "7-8 hours" $(=3)$ & $38 \%$ & $35 \%$ & $39 \%$ \\
\hline & "8-9 hours" $(=4)$ & $6 \%$ & $5 \%$ & $6 \%$ \\
\hline & "over 9 hours" $(=5)$ & $0 \%$ & $0 \%$ & $0 \%$ \\
\hline \multirow[t]{5}{*}{ sector } & Area of activity of the employer: & & & \\
\hline & R\&D institutes $(=1$, base $)$ & $20 \%$ & $19 \%$ & $21 \%$ \\
\hline & private $\mathrm{R} \& \mathrm{D}$ companies $(=2)$ & $14 \%$ & $11 \%$ & $15 \%$ \\
\hline & private IT and technology companies $(=3)$ & $37 \%$ & $46 \%$ & $34 \%$ \\
\hline & IT and product development units at commercial banks $(=4)$ & $29 \%$ & $24 \%$ & $30 \%$ \\
\hline
\end{tabular}

Note: mean and standard deviation shown for continuous and ordered variables; percentage of respondents shown for binary and categorical variables 
Table A2. Ordered probit estimates

\begin{tabular}{|c|c|c|c|c|c|c|}
\hline & Model 1 & Model 2 & Model 3 & Model 4 & Model 5 & Model 6 \\
\hline Variable & $\begin{array}{l}\text { satisfied: } \\
\text { flextime }=0\end{array}$ & $\begin{array}{l}\text { satisfied: } \\
\text { flextime }=1\end{array}$ & creaimpede & pace & worknature & colleagues \\
\hline creatime & $\begin{array}{l}-0.071 * * * \\
(0.02)\end{array}$ & $\begin{array}{l}0.019 * * * \\
(0.00)\end{array}$ & $\begin{array}{l}-0.012 * * * \\
(0.00)\end{array}$ & $\begin{array}{l}0.007 \\
(0.01)\end{array}$ & $\begin{array}{l}-0.008 * \\
(0.00)\end{array}$ & $\begin{array}{l}-0.019 * * * \\
(0.00)\end{array}$ \\
\hline workhours & $\begin{array}{l}-0.898 * * * \\
(0.19)\end{array}$ & $\begin{array}{l}0.070 \\
(0.10)\end{array}$ & $\begin{array}{l}0.147 * \\
(0.08)\end{array}$ & $\begin{array}{l}0.068 \\
(0.06)\end{array}$ & $\begin{array}{l}0.086 \\
(0.08)\end{array}$ & $\begin{array}{l}0.047 \\
(0.06)\end{array}$ \\
\hline place $=1$ & $\begin{array}{l}1.888 * * * \\
(0.51)\end{array}$ & $\begin{array}{l}0.995 * * \\
(0.48)\end{array}$ & & & & \\
\hline flextime $=0$, place $=1$ & & & $\begin{array}{l}-0.524 \\
(0.71)\end{array}$ & $\begin{array}{l}-0.650 \\
(0.56)\end{array}$ & $\begin{array}{l}0.196 \\
(0.37)\end{array}$ & $\begin{array}{l}0.039 \\
(0.47)\end{array}$ \\
\hline flextime $=1$, place $=0$ & & & $\begin{array}{l}-0.296^{*} \\
(0.18)\end{array}$ & $\begin{array}{l}0.158 \\
(0.21)\end{array}$ & $\begin{array}{l}0.216 \\
(0.16)\end{array}$ & $\begin{array}{l}0.389 \\
(0.34)\end{array}$ \\
\hline flextime $=1$, place $=1$ & & & $\begin{array}{l}-0.880 * * * \\
(0.30)\end{array}$ & $\begin{array}{l}0.872 * * \\
(0.38)\end{array}$ & $\begin{array}{l}0.089 \\
(0.40)\end{array}$ & $\begin{array}{l}-0.555^{*} \\
(0.31)\end{array}$ \\
\hline atwork & $\begin{array}{l}-17.959 * * * \neq \\
(5.42)\end{array}$ & $\begin{array}{l}-1.889^{¥} \\
(1.25)\end{array}$ & $\begin{array}{l}1.014 \\
(1.04)\end{array}$ & $\begin{array}{l}0.449 \\
(0.80)\end{array}$ & $\begin{array}{l}0.670 \\
(1.49)\end{array}$ & $\begin{array}{l}0.412 \\
(0.81)\end{array}$ \\
\hline nature $=2$ & $\begin{array}{l}0.477 \\
(1.28)\end{array}$ & $\begin{array}{l}0.069 \\
(0.43)\end{array}$ & $\begin{array}{l}0.158 \\
(0.41)\end{array}$ & $\begin{array}{l}0.203 \\
(0.25)\end{array}$ & $\begin{array}{l}0.474 * * \\
(0.22)\end{array}$ & $\begin{array}{l}-0.137 \\
(0.27)\end{array}$ \\
\hline nature $=3$ & & $\begin{array}{l}-0.941 * * \hbar \\
(0.46)\end{array}$ & $\begin{array}{l}-0.637 \\
(0.88)\end{array}$ & $\begin{array}{l}-1.082^{* * *} \\
(0.51)\end{array}$ & $\begin{array}{l}0.506 \\
(0.90)\end{array}$ & $\begin{array}{l}-1.699 * * * \\
(0.51)\end{array}$ \\
\hline salary & $\begin{array}{l}-0.484 \\
(0.38)\end{array}$ & $\begin{array}{l}-0.127 \\
(0.28)\end{array}$ & $\begin{array}{l}-0.136 \\
(0.28)\end{array}$ & $\begin{array}{l}0.066 \\
(0.17)\end{array}$ & $\begin{array}{l}0.429 * * \\
(0.17)\end{array}$ & $\begin{array}{l}-0.138 \\
(0.10)\end{array}$ \\
\hline age & $\begin{array}{l}0.049 * * \\
(0.02)\end{array}$ & $\begin{array}{l}-0.028^{\ddagger} \\
(0.02)\end{array}$ & $\begin{array}{l}0.014^{¥} \\
(0.01)\end{array}$ & $\begin{array}{l}0.019 * \\
(0.01)\end{array}$ & $\begin{array}{l}-0.010 \\
(0.01)\end{array}$ & $\begin{array}{l}-0.006 \\
(0.01)\end{array}$ \\
\hline gender $($ Male $=1)$ & $\begin{array}{l}0.780 * * * \\
(0.30)\end{array}$ & $\begin{array}{l}0.402 * * * \\
(0.15)\end{array}$ & $\begin{array}{l}-0.746 * * * \\
(0.15)\end{array}$ & $\begin{array}{l}-0.038 \\
(0.26)\end{array}$ & $\begin{array}{l}-0.212 \\
(0.24)\end{array}$ & $\begin{array}{l}-0.403^{*} \\
(0.24)\end{array}$ \\
\hline family & $\begin{array}{l}0.271 \\
(0.24)\end{array}$ & $\begin{array}{l}0.092 \\
(0.08)\end{array}$ & $\begin{array}{l}-0.058 \\
(0.07)\end{array}$ & $\begin{array}{l}-0.094 \\
(0.08)\end{array}$ & $\begin{array}{l}-0.027 \\
(0.03)\end{array}$ & $\begin{array}{l}0.131 \\
(0.11)\end{array}$ \\
\hline education & $\begin{array}{l}0.375 * * * \\
(0.10)\end{array}$ & $\begin{array}{l}0.079 \\
(0.06)\end{array}$ & $\begin{array}{l}-0.144 * * * \\
(0.05)\end{array}$ & $\begin{array}{l}0.069 \\
(0.06)\end{array}$ & $\begin{array}{l}-0.057 \\
(0.04)\end{array}$ & $\begin{array}{l}-0.027 \\
(0.13)\end{array}$ \\
\hline phealth & $\begin{array}{l}0.024 \\
(0.14)\end{array}$ & $\begin{array}{l}-0.003 \\
(0.11)\end{array}$ & $\begin{array}{l}0.041 \\
(0.06)\end{array}$ & $\begin{array}{l}0.140 * * * \\
(0.04)\end{array}$ & $\begin{array}{l}0.122 * \\
(0.07)\end{array}$ & $\begin{array}{l}0.006 \\
(0.09)\end{array}$ \\
\hline meq & $\begin{array}{l}-0.102 \\
(0.08)\end{array}$ & $\begin{array}{l}0.097 * * \\
(0.04)\end{array}$ & $\begin{array}{l}-0.023 \\
(0.02)\end{array}$ & $\begin{array}{l}0.037 * \\
(0.02)\end{array}$ & $\begin{array}{l}-0.022 \\
(0.02)\end{array}$ & $\begin{array}{l}0.043 \\
(0.03)\end{array}$ \\
\hline sleephours & $\begin{array}{l}0.089 \\
(0.49)\end{array}$ & $\begin{array}{l}0.080 \\
(0.15)\end{array}$ & $\begin{array}{l}-0.254 \\
(0.20)\end{array}$ & $\begin{array}{l}0.140 \\
(0.13)\end{array}$ & $\begin{array}{l}-0.033 \\
(0.19)\end{array}$ & $\begin{array}{l}-0.070 \\
(0.13)\end{array}$ \\
\hline sector $=2$ & $\begin{array}{l}1.347 * * \\
(0.65)\end{array}$ & $\begin{array}{l}-0.218 \\
(0.40)\end{array}$ & $\begin{array}{l}1.235 * * * \\
(0.40)\end{array}$ & $\begin{array}{l}0.286 \\
(0.35)\end{array}$ & $\begin{array}{l}-0.360 \\
(0.27)\end{array}$ & $\begin{array}{l}0.330 \\
(0.39)\end{array}$ \\
\hline sector $=3$ & $\begin{array}{l}0.046 \\
(0.83)\end{array}$ & $\begin{array}{l}-1.288^{* *} \\
(0.65)\end{array}$ & $\begin{array}{l}1.203^{*} \\
(0.64)\end{array}$ & $\begin{array}{l}-0.470 * \\
(0.26)\end{array}$ & $\begin{array}{l}-0.088 \\
(0.36)\end{array}$ & $\begin{array}{l}-0.282 \\
(0.43)\end{array}$ \\
\hline sector $=4$ & $\begin{array}{l}-1.520 \\
(1.18)\end{array}$ & $\begin{array}{l}-0.313 \\
(0.46) \\
\end{array}$ & $\begin{array}{l}1.077 * \\
(0.61)\end{array}$ & $\begin{array}{l}-0.668^{* * *} \\
(0.32)\end{array}$ & $\begin{array}{l}-0.258 \\
(0.44) \\
\end{array}$ & $\begin{array}{l}0.309 \\
(0.38) \\
\end{array}$ \\
\hline cut1 & $\begin{array}{l}-25.628 * * * \\
(8.14)\end{array}$ & $\begin{array}{l}-1.506 \\
(2.28)\end{array}$ & $\begin{array}{l}-2.516 \\
(2.41)\end{array}$ & $\begin{array}{l}0.594 \\
(1.76)\end{array}$ & $\begin{array}{l}-0.743 \\
(2.17)\end{array}$ & $\begin{array}{l}-0.479 \\
(2.04)\end{array}$ \\
\hline cut2 & $\begin{array}{l}-23.482 * * * \\
(7.47)\end{array}$ & $\begin{array}{l}0.602 \\
(2.38)\end{array}$ & $\begin{array}{l}-0.321 \\
(2.57)\end{array}$ & $\begin{array}{l}2.366^{\ddagger} \\
(1.58)\end{array}$ & $\begin{array}{l}-0.061 \\
(2.23)\end{array}$ & $\begin{array}{l}0.182 \\
(1.97)\end{array}$ \\
\hline cut3 & $\begin{array}{l}-20.684 * * * \\
(7.47)\end{array}$ & $\begin{array}{l}3.097 \\
(2.42)\end{array}$ & $\begin{array}{l}0.397 \\
(2.53)\end{array}$ & $\begin{array}{l}3.394 * * \\
(1.66)\end{array}$ & $\begin{array}{l}0.789 \\
(2.30)\end{array}$ & $\begin{array}{l}1.111 \\
(1.97)\end{array}$ \\
\hline cut4 & $\begin{array}{l}-15.805 * * \\
(6.86)\end{array}$ & & $\begin{array}{l}2.125 \\
(2.74)\end{array}$ & $\begin{array}{l}5.132 * * * \\
(1.80)\end{array}$ & $\begin{array}{l}1.773 \\
(2.20)\end{array}$ & \\
\hline Pseudo- $\mathrm{R}^{2}$ & 0.53 & 0.31 & 0.25 & 0.17 & 0.06 & 0.11 \\
\hline Pseudo-log-likelihood & $-22.4 * * *$ & $-73.5 * * *$ & $-124.5 * * *$ & $-146.7 * * *$ & $-208.7 * * *$ & $-133.0 * * *$ \\
\hline No of obs. & 37 & 109 & 146 & 146 & 146 & 146 \\
\hline
\end{tabular}

Note: ${ }^{*} p<0.15, * p<0.10, * * p<0.05, * * * p<0.01$; significance of pseudo-log-likelihoods is based on the Wald's chi ${ }^{2} ;{ }^{*}$ only 4 observations in this category making the regression results for these irrelevant. 
Table A3. Multivariate ordered probit estimate

\begin{tabular}{|c|c|c|c|c|}
\hline Variable & Creaimpede & pace & worknature & colleagues \\
\hline \multirow[t]{2}{*}{ creatime } & $-0.012 * * *$ & 0.007 & $-0.008 *$ & $-0.019 * * *$ \\
\hline & $(0.00)$ & $(0.01)$ & $(0.00)$ & $(0.00)$ \\
\hline \multirow[t]{2}{*}{ workhours } & $0.140^{*}$ & 0.072 & 0.081 & 0.061 \\
\hline & $(0.08)$ & $(0.06)$ & $(0.09)$ & $(0.06)$ \\
\hline \multirow[t]{2}{*}{ flextime $=0$, place $=1$} & -0.393 & -0.647 & 0.204 & -0.057 \\
\hline & $(0.72)$ & $(0.57)$ & $(0.36)$ & $(0.47)$ \\
\hline \multirow[t]{2}{*}{ flextime $=1$, place $=0$} & $-0.258^{*}$ & 0.167 & 0.209 & 0.353 \\
\hline & $(0.16)$ & $(0.20)$ & $(0.16)$ & $(0.33)$ \\
\hline \multirow[t]{2}{*}{ flextime $=1$, place $=1$} & $-0.876^{* * *}$ & $0.884 * *$ & 0.086 & $-0.659 * *$ \\
\hline & $(0.29)$ & $(0.39)$ & $(0.40)$ & $(0.33)$ \\
\hline \multirow[t]{2}{*}{ atwork } & 0.968 & 0.421 & 0.657 & 0.498 \\
\hline & $(1.02)$ & $(0.80)$ & $(1.50)$ & $(0.80)$ \\
\hline \multirow[t]{2}{*}{ nature $=2$} & 0.157 & 0.216 & $0.471 * *$ & -0.217 \\
\hline & $(0.43)$ & $(0.25)$ & $(0.22)$ & $(0.28)$ \\
\hline \multirow[t]{2}{*}{ nature $=3$} & -0.599 & $-1.121 * *$ & 0.508 & $-1.667 * * *$ \\
\hline & $(0.81)$ & $(0.48)$ & $(0.90)$ & $(0.56)$ \\
\hline \multirow[t]{2}{*}{ salary } & -0.143 & 0.050 & $0.433 * * *$ & $-0.132^{¥}$ \\
\hline & $(0.28)$ & $(0.17)$ & $(0.17)$ & $(0.08)$ \\
\hline \multirow[t]{2}{*}{ age } & $0.013^{¥}$ & $0.019 *$ & -0.010 & -0.006 \\
\hline & $(0.01)$ & $(0.01)$ & $(0.01)$ & $(0.01)$ \\
\hline \multirow[t]{2}{*}{ gender $($ Male=1) } & $-0.784 * * *$ & -0.030 & -0.217 & $-0.406^{*}$ \\
\hline & $(0.16)$ & $(0.25)$ & $(0.24)$ & $(0.24)$ \\
\hline \multirow[t]{2}{*}{ family } & -0.060 & -0.095 & -0.026 & 0.131 \\
\hline & $(0.07)$ & $(0.08)$ & $(0.03)$ & $(0.11)$ \\
\hline \multirow[t]{2}{*}{ educationy } & $-0.148 * * *$ & 0.069 & -0.056 & -0.022 \\
\hline & $(0.05)$ & $(0.06)$ & $(0.05)$ & $(0.13)$ \\
\hline \multirow[t]{2}{*}{ phealth } & 0.046 & $0.136 * * *$ & $0.122 *$ & 0.006 \\
\hline & $(0.06)$ & $(0.04)$ & $(0.07)$ & (0.09) \\
\hline \multirow[t]{2}{*}{ meq } & -0.024 & $0.038^{*}$ & -0.022 & 0.039 \\
\hline & $(0.02)$ & $(0.02)$ & $(0.02)$ & $(0.03)$ \\
\hline \multirow[t]{2}{*}{ sleephours } & -0.239 & 0.135 & -0.032 & -0.051 \\
\hline & $(0.19)$ & $(0.13)$ & $(0.19)$ & $(0.13)$ \\
\hline \multirow[t]{2}{*}{ sector $=2$} & $1.234 * * *$ & 0.283 & -0.369 & 0.344 \\
\hline & $(0.44)$ & $(0.37)$ & $(0.28)$ & $(0.42)$ \\
\hline \multirow[t]{2}{*}{ sector $=3$} & $1.224 *$ & $-0.453^{*}$ & -0.091 & -0.268 \\
\hline & (0.69) & $(0.26)$ & $(0.36)$ & $(0.42)$ \\
\hline \multirow[t]{2}{*}{ sector $=4$} & $1.080 *$ & $-0.659 * *$ & -0.255 & 0.337 \\
\hline & $(0.66)$ & $(0.33)$ & $(0.44)$ & $(0.40)$ \\
\hline cut1 & -2.719 & 0.843 & -0.795 & -0.227 \\
\hline & (2.39) & (1.83) & $(2.20)$ & $(2.06)$ \\
\hline cut 2 & -0.530 & $2.439^{¥}$ & -0.109 & 0.421 \\
\hline & $(2.56)$ & (1.66) & $(2.27)$ & (1.98) \\
\hline cut3 & 0.118 & $3.400 * *$ & 0.743 & 1.324 \\
\hline & $(2.52)$ & $(1.70)$ & $(2.34)$ & (1.99) \\
\hline cut4 & 1.646 & $5.153 * * *$ & 1.713 & \\
\hline & $(2.74)$ & $(1.84)$ & $(2.23)$ & \\
\hline atanhrho creaimpede & & $-0.519 * * *$ & $0.194^{¥}$ & $0.402 * * *$ \\
\hline & & $(0.13)$ & $(0.13)$ & $(0.13)$ \\
\hline atanhrho pace & & & -0.156 & $-0.292 *$ \\
\hline & & & $(0.15)$ & $(0.16)$ \\
\hline atanhrho worknature & & & & 0.059 \\
\hline & & & & $(0.11)$ \\
\hline Pseudo-log-likelihood & $-595.3 * * *$ & & & \\
\hline No of obs. & 146 & & & \\
\hline
\end{tabular}

Note: ${ }^{*} p<0.15, * p<0.10, * * p<0.05, * * * p<0.01$; significance of pseudo-log-likelihood is based on the Wald's chi ${ }^{2}$ 